\title{
Comparison Effectiveness of Conventional and Islamic Monetary Policiesto Controlling Inflation in Indonesia Period 2012-2018
}

\section{Salma Nur Hasna, Kusnendi, and Neni Sri Wulandari}

Economics and Islamic Finance Department, Universitas Pendidikan Indonesia Jl. Dr. Setiabudhi No. 229 Kota Bandung

\section{Abstract}

This study aims to know the extent influence and effectiveness of conventional monetary policy that reflected by the interest rates of Bank Indonesia Certificates (SBI), total loans of conventional bank (LOAN) and the average Government Bonds yield (SUN) and Islamic monetary policy that reflected by the rates of return on Bank Indonesia Sharia Certificates (SBIS), total financing of Islamic bank (FINC) and the average Islamic Government Bonds yield (SBSN) to controlling inflation Indonesia in 2012-2018. The analysis method used in this study is Vector Error Correction Model

Corresponding Author:

Salma Nur Hasna

salmanurhasna@student.upi.edu

Received: 10 February 2019

Accepted: 14 March 2019

Published: 28 March 2019

Publishing services provided by Knowledge E

(c) Salma Nur Hasna et al. This article is distributed under the terms of the Creative Commons Attribution License, which permits unrestricted use and redistribution provided that the original author and source are credited.

Selection and Peer-review under the responsibility of the ICIEBP Conference Committee.

\section{G OPEN ACCESS} (VECM). The VECM results show that in the short term only SBSN has a significant effect on inflation, but that efect is positive (increasing inflation). In addition in the long term, SBI has a significant negative effect while FINC, SUN and SBSN have a significant positive effect. The effectiveness which is measured by Impulse Response Function (IRF) and Forecast Error Variance Decomposition (FEVD) shows that conventional monetary policy is faster in stabilizing inflation but the scope is small, while Islamic monetary policy is slower in stabilizing inflation but the scope is bigger.

Keywords: Inflation, Dual Monetary Policy, Interest Rate Channel, Loans Channel, Asset Price Channel

\section{Introduction}

Most economists tend to agree that inflation is still the biggest market economy problem faced by various countries. Inflation is a state of increasing prices of goods or services that generally and continuously (Karlina, 2017). If inflation does not heal immediately, it can trigger recession and even depression (Yuliadi, Kusuma, \& Syahputra, 2016).

Indonesia is a developing country whose economic development cannot be separated from the inflation conditions that always accompany it (Setiawan, 2009). It can be seen in Figure 1, Indonesia's inflation rate fluctuated where most of it was still out of control as expected. The inflation rate below is measured using the Consumer Price 
Index (CPI), which is the index number that describes changes in prices of goods and services consumed by the general public in a given period with a predetermined period of time (Karlina, 2017).

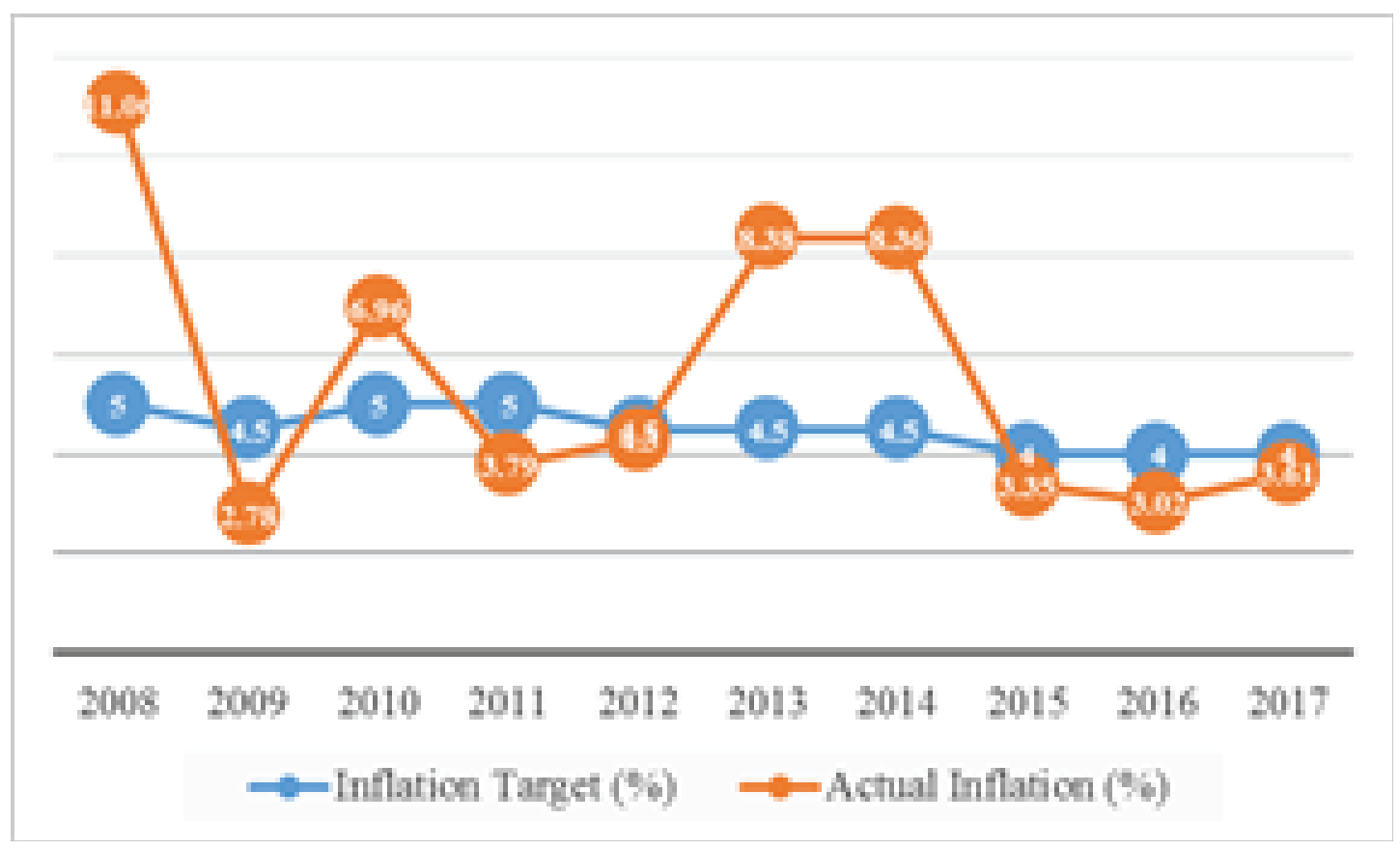

Figure 1: Indonesia's CPI Period 2008-2017 (Source: Bank Indonesia (2017)).

Based on Figure 1, it can be seen that in the last 10 years most of the inflation rate is still uncontrolled because actual inflation is still much larger or smaller than the inflation target. This happened because many upheavals in the prices of goods and services in transactions, natural phenomena, and government policies. From these data, the highest inflation occurred in 2008 due to the global crisis, while the lowest inflation occurred in 2009, which occurred after the global crisis because the public attracted a lot of money from market circulation, followed by 2016 when people's purchasing power was declining. The general annual inflation rate for Indonesia over the past 10 years is $5.58 \%$ or rounded up to $6 \%$ per year (Salju, 2017).

Based on research Sutawijaya \& Zulfahmi (2012) and Setyawan (2010), from the conventional perspective of causes of inflation are rising prices of production factors (cost push), increased demand for commodities produced by production under conditions of unemployment (demand pull), and mixed (mixed). Meanwhile Al-Arif (2010) states that the Islamic paradigm emphasizes that inflation is the result of natural mistakes in terms of demand and supply and human error such as excessive consumption.

Therefore, controlling inflation is very important to be one of the Government's concerns in various countries, especially Indonesia (Sutawijaya A., 2012). The Indonesian government designed various monetary policy applications to controlling inflation 
problems. Monetary policy is a macroeconomic policy managed by the Central Bank with the aim of influencing the level of economic activity by monitoring the Amount of Money in Circulation (JUB) or interest rate (Setyawan, 2010). The ultimate goal of monetary policy is to maintain and maintain the stability of the rupiah which is reflected in the low and stable inflation rate (BI, 2017).

The monetary policy of a monetary authority is intended to influence real economic activities and prices through the transmission mechanism that occurs (Ascarya, 2012). The monetary policy transmission mechanism can work through various channels, such as interest rates, credit, asset prices, exchange rates and expectations (Ascarya, 2010). The mechanism is carried out by Indonesia by implementing conventional and Islamic systems side by side (Yuliadi, Kusuma, \& Syahputra, 2016).

But unfortunately the monetary policy implemented is still one of the causes of the inflation problem itself. This is as the result of the study Ascarya (2013) which states that one of the root causes of the financial crisis is instability and injustice of the monetary or financial system. The current monetary policy will create a higher inflation rate and trigger an economic crisis in the long term (Putriani \& Prastowo., 2014). Experience in many countries shows that the ultimate goal of monetary policy cannot be achieved simultaneously and sustainably, and there is even a tendency to be contradictory because of dual aims (Natsir, 2008).

The solution is that the Central Bank needs to establish the achievement of the inflation target and determine which transmission lines are more dominant because it has more influence on the economy (Hasibuan, 2015). This is as stated Ascarya (2012) that the monetary authority must have a clear understanding of the transmission mechanism in its country. Because, if the transmission mechanism is poorly understood, monetary policy that is set is not credible (Hasibuan, 2015).

In addition, the global economy will cause shocks that can affect the condition of the national economy. To reduce the impact of the global economic shock on the domestic economy, effective and efficient policies are needed, both monetary and fiscal policies and other economic policies. (Herlina, 2013).

The effectiveness of the monetary policy transmission mechanism (MTKM) can be measured by two indicators, the first by measuring how much speed or deadline (time lag) and the second by measuring how much strength the variables respond to the shock until the realization of a stable inflation rate. Both indicators are obtained from the Impulse Response Function (IRF) Test and Forecast Error Variance Decomposition Test (FEVD) in the data analysis of Vector Error Correction Model (VECM) (Natsir, 2008). 
In fact, the research on the monetary policy transmission mechanism (MTKM) provides an explanation of how the changes in monetary policy instruments can influence other macroeconomic variables until the ultimate monetary policy objective is realized (Natsir, 2008). Based on research Noviasari A. (2012), monetary policy to reduce inflation with Sharia patterns is more effective than conventional patterns. This is in line with the results of the study Fauziyah (2015), stating that the flow of the mechanism of Islamic monetary transmission through the asset price channel has a better mechanism than the flow of conventional monetary transmission mechanisms through the path of asset prices in influencing inflation.

In addition, the results of the study Herianingrum \& Syapriatama (2016), stated that compared with conventional monetary policy, Islamic monetary policy can meet macroeconomic objectives, namely output growth and low inflation. As for 'Ayuniyyah, Achsani, \& Ascarya. (2010), stated that the Islamic monetary policy reflected in the Bank Indonesia Sharia Certificate (SBIS) turned out to have a significant impact on the Industrial Production Index (IPI). Whereas conventional monetary policies reflected in Bank Indonesia Certificates (SBIs) do not have a significant impact on the Industrial Production Index (IPI).

Although there have been many studies on the role of MTKM concerning its effectiveness, there are still uncertainties and new trends that can affect the MTKM, so further research on the problem remains relevant to do (Natsir, 2008). Therefore, the authors are interested in conducting this research by focusing on monetary policy in three main lines, namely the interest rate path and profit sharing rate, credit \& financing channels, and asset price channels. This study is entitled "Comparison Effectiveness of Conventional and Islamic Monetary Policies to Controlling Inflation in Indonesia Period 2012-2018" by using the Vector Error Correction Model (VECM) method in order to determine the extent and influence of the conventional and islamic monetary policy variables on inflation.

Based on the explanation above, the central theme in this study is the uncontrolled problem of inflation due to the still low effectiveness of the application of the transmission mechanism of conventional and sharia monetary policies side by side. So what needs to be done is to measure the effectiveness of the application of the transmission mechanism of conventional and islamic monetary policy by looking at any monetary variables that are more influential and more effective to implement.So the formulation of the problem proposed is the extent to which the influence and effectiveness of conventional monetary policies are reflected in the interest rates of Bank Indonesia Certificates (SBI), Total Loans of Conventional Bank (LOAN) and the average Government 
Bonds Yield (SUN) on Inflation rates. The extent to which the influence and effectiveness of Islamic monetary policy are reflected by the rates of return on Bank Indonesia Sharia Certificates (SBIS), Total Financing of Islamic Bank (FINC) and average Islamic Government Bonds Yield (SBSN) on Inflation rates.

Based on the problems described above, in general the purpose of this research is to obtain knowledge about conventional and sharia monetary policies that Indonesia has adopted in controlling inflation. In essence, this study aims to see how the influence and effectiveness of Bank Indonesia Certificates (SBI) and Bank Indonesia Sharia Certificates (SBIS) as a transmission mechanism for interest rate / profit sharing monetary policy, Total Loans of Conventional Bank (LOAN) and Total Financing of Islamic Bank (FINC) as a transmission mechanism of the credit / financing lending monetary policy, as well as Government Bonds Yield (SUN) and Islamic Government Bonds=s Yield (SBSN) as a mechanism for transmitting monetary policy on asset prices to inflation.

There are eight hypotheses proposed in this study. First, the Interest Rate of Bank Indonesia Certificates (SBI) has a negative effect on the Inflation Rate. Second, Bank Indonesia Sharia Certificate (SBIS) Yields has a negative effect on the Inflation Rate. Third, Total Loans of Conventional Bank (LOAN) has a positive effect on the Inflation Rate. Fourth, Total Financing of Islamic Bank (FINC) has a negative effect on the Inflation Rate. Fifth, Government Bonds Yield (SUN) has a positive effect on the Inflation Rate. Sixth, the Islamic Government Bonds Yield (SBSN) has a negative effect on the Inflation Rate. Seventh, the Conventional Monetary Policy are reflected by SBI, LOAN and SUN is effective. Eighth, Islamic monetary policy are reflected by effective SBI, LOAN and SUN.

\section{Literature Review}

\subsection{Inflation}

Inflation is a tendency to increase prices in general from goods and services products as a whole over a period of time (Karim, 2015). A condition can be said to be inflation if there are three components. First, there is a tendency to increase prices, even though at a certain time there is a decrease or increase compared to before. Second, the price increases that occur are general, meaning that an increase in prices is not experienced by just one or several commodities. Third, price increases take place continuously, not only at one time (Rahardja \& Manurung, 2004). 
In Islamic economics, inflation is not known, because the currency used is dinar and dirham in the form of gold and silver, which has a stable value and is justified by Islam. This is in line with Riani (2003) which reveals that the term inflation has never been explicitly stated in the Qur'an or Hadith. Inflation is a modern problem that arises because of several reasons, including the public's desire for excessive consumption. From this point of view, long before the onset of inflation the arguments in the Qur'an and Hadith have given instructions, as follows:

1. Q.S. Ali-Imran (3): 14

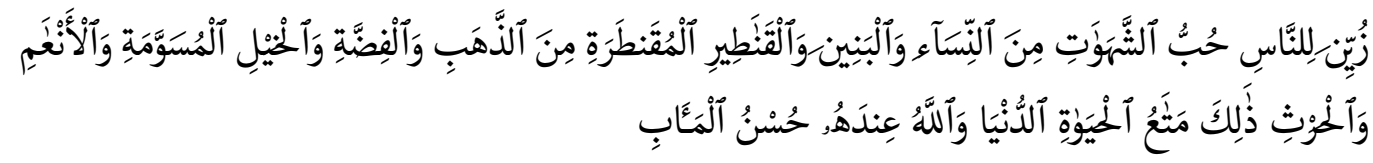

Meaning: "It is made to be beautiful in the human view of love for what it wants, namely women, children, wealth of gold, silver, selected horses, livestock and fields..."

2. HR. Muslim

Meaning: "It is very bad for people who are enslaved by property (capital), either in the form of currency (dinar), silver coins (dirham), or others."

\subsection{Monetary policy}

Monetary policy is the politics of the state in determining regulations and actions in state finances. More specifically, monetary policy has the meaning of a Government macro action through the central bank by influencing the creation of money (Ascarya, 2012). By influencing the process of money creation, the Government can influence the money supply, affect investment spending, affect aggregate demand and ultimately the price level so as to create economic conditions as desired (Wahyudi, 2013).

In principle, the objective of Islamic monetary policy is no different from the objective of conventional monetary policy, namely to maintain the stability of the currency so that equitable economic growth is achieved. Stability in the value of money cannot be separated from the goal of sincerity and openness in muamalah, which is reflected in Q.S. Al-An'am: 152, as follows:

Meaning: "... And complete the measures and scales fairly..."

Monetary policy is applied through various transmissions. Monetary policy transmission is an interaction that occurs through two stages of the money circulation process between the central bank as the monetary authority with banks and other financial 
institutions; and other economic actors in the real sector (Sugianto, Harmain, \& Harahap, 2015).

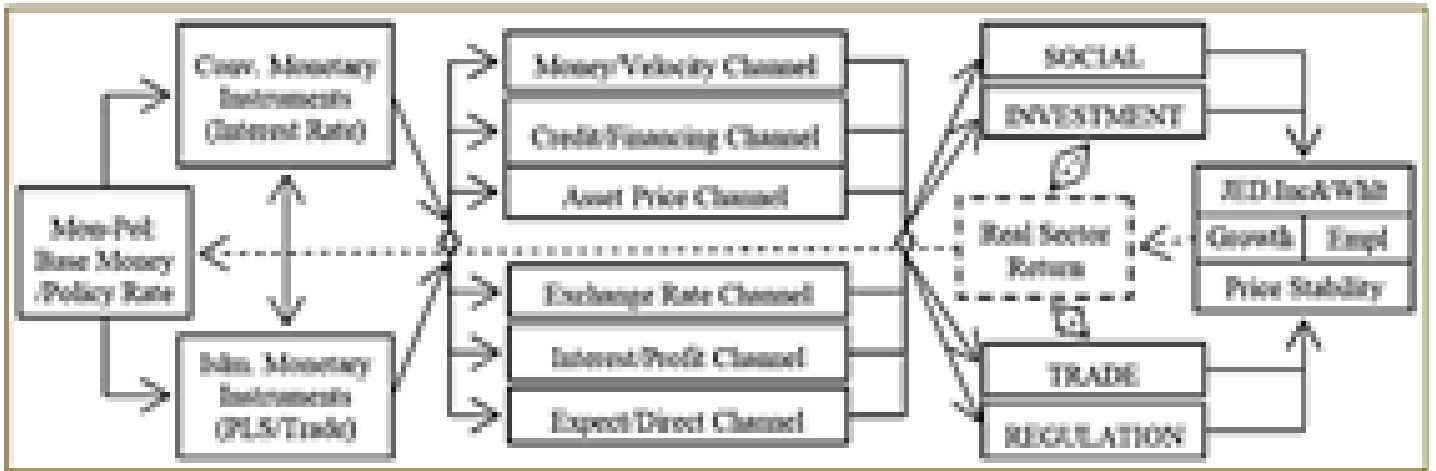

Figure 2: Monetary Policy Transmission Mechanism under the Dual Financial System (Source: Ascarya (2014)).

\subsection{Interest rate and yields channel}

The interest rate path was originally introduced in the 1936 Keynes General Theory. This pathway has become a key mechanism in the basic model of Keynesian IS-LM. This model shows the supply and demand for money which explains how interest rates and total output are produced in the economy, given the fixed price level. The expansion of monetary policy $(\mathrm{M} \uparrow$ ) leads to a decrease in real interest rates $(r \downarrow)$, which in turn decreases the cost of capital and causes an increase in investment expenditure $(I \uparrow)$, thus leading to an increase in aggregate demand and an increase in output $(\mathrm{Y} \uparrow$ ) (Ascarya, 2014).

\subsubsection{Bank Indonesia certificates (SBI)}

Bank Indonesia Certificates (SBI) are money market instruments to control economic liquidity by keeping optimal amounts of money in circulation and preventing increased demand for funds by the public and national private entrepreneurs for transaction purposes. For the short term, SBls are used as a benchmark for government, national and foreign private banks in determining interest rates on savings, time deposits and loans (Hismendi, Hamzah, \& Musnadi, 2013). 


\subsubsection{Bank Indonesia Sharia certificates (SBIS)}

SBIS is short-term securities based on sharia principles in rupiah currency issued by Bank Indonesia in order to improve the effectiveness of the monetary mechanism with sharia principles (Daniar, 2016).

\subsection{Credit and financing channel}

The approach to the transmission mechanism of monetary policy through credit channels is based on the assumption that not all public deposits are in the form of money (M1 and M2), but distributed by banks to the public in the form of credit or financing. In other words, the banking intermediary function does not always run perfectly, where the increase in public savings is not always followed by a proportional increase in credit disbursed to the public. What is more influential on the real economy is bank credit, not public savings (Rusydiana, 2009).

\subsubsection{Total loans of conventional bank (LOAN)}

Total Loans of Conventional Bank (LOAN) is a bank expenditure in the form of credit with the principle of interest. The principle of interest is the principle of the percentage of funds loaned at the beginning of a transaction regardless of the profit or loss that will occur later (Ascarya, Hasanah, \& Achsani, 2008). Total Loans of Conventional Bank (LOAN) can be classified based on the type of usage, namely Working Capital, Investment and Consumption.

\subsubsection{Total financing of Islamic bank (FINC)}

Financing is funding that is spent to support planned investments (Yusuf \& Sari, 2013). The Total Financing of Islamic Bank (FINC) consists of profit sharing transactions, buying and selling, leasing and loans. FINC is prioritized to encourage the movement of the real sector, especially cooperation products or profit sharing. The financing of this cooperation will have an impact on the productivity of the community in creating goods and services and increasing people's income (Asnuri, 2013). From a monetary perspective, FINC is used to increase the money supply (Daniar, 2016). 


\subsection{Asset price channel}

Monetary policy through asset prices is a monetary policy that influences the development of prices of other assets, both the price of financial assets such as Bonds, sukuk and stocks and physical assets, especially property prices and gold. Changes in interest rates, exchange rates and the amount of investment in the money market will also affect the volume and price of Bonds, sukuk, shares and physical assets. Furthermore, asset prices on consumption and investment will also affect aggregate demand which will ultimately determine the level of real output and inflation in the economy (Fauziyah, 2015).

\subsubsection{Government bonds (SUN)}

Goverment bonds (SUN) are securities in the form of letters of acknowledgment of debt that are guaranteed interest and principal payments by the Republic of Indonesia in accordance with the validity period. In general, the types of SUN can be divided into two. First, State Treasury Bills (SPN), namely SUN with a 12-month term with discounted interest payments. Secondly, Government Bonds (ON), namely SUN with a maturity of more than 12 months either with coupons or without coupons (Direktorat Jenderal Pengelolaan Utang, 2018).

SUN yields that fluctuate affect the level of the SUN market price itself. Therefore, investors and issuers will pay attention to price fluctuations and changes in SUN yields (Surya \& Nasher, 2011). The rising interest rate caused SUN prices to fall so that the market yield also dropped (Finansial Bisnis, 2012).

\subsubsection{Islamic government bonds (SBSN)}

Monetaryly, issuing islamic government bonds is one of the Government's steps to reduce money circulating back to the central bank (Daniar, 2016). Islamic government bonds are State securities issued based on sharia principles as proof of the share of participation in SBSN assets, both in rupiah and foreign currency (Direktorat Jenderal Pengelolaan Utang, 2018). Islamic government bonds can be issued as long as it does not conflict with sharia principles. 


\section{Methodology}

This study focuses on dual monetary policy in Indonesia to controlling inflation. Conventional monetary policy is reflected by interest rates of Bank Indonesia Certificates (SBI), total Loans of Conventional Bank (LOAN) and average yield of Government Bonds (SUN). Meanwhile, Islamic monetary policy is reflected by rate of return of Bank Indonesia Sharia Certificates (SBIS), total Financing of Islamic Bank (FINC) and average yield of Islamic government bonds (SBSN). The research subject is the inflation rate. Research data was taken in period August 2012 to April 2018 from several official websites, namely Bank Indonesia (BI), Financial Services Authority (OJK) and Ministry of Finance (Kemenkeu).

The method used in this study is a quantitative descriptive method with a causal relationship (causality). Quantitative research is an approach for testing objective theories by examining the relationship among variables (Creswell, 2014). In addition, the design of this study is an explanatory design that aims to explain the relationship between two or more (Silalahi, 2012). In this study there are seven variables that are allegedly related to or influence each other.

Data analysis techniques in this study were carried out through a series of testing stages using the Vector Error Correction Model (VECM) analyst. VECM is a form of VAR that is estimated because of the existence of cointegrated data. The VECM specification restores the long-term relationships of endogenous variables in order to converge into their cointegration relationships, but still allow the existence of short-term dynamics (Basuki \& Yusuf, 2018).

The data analysis technique used in this study is VECM analysis using Eviews 8 software tools. The first step is to test the data by stationary test, determine optimum lag, stability test and cointegration tests. Furthermore, influence variables in the model can be test with Engel-Granger and VECM causality tests. While, the effectiveness can be test through Impulse Response Function (IRF) and Forecast Error Variance Decomposition (FEVD) tests.

\section{Result}

Stationary Test (Unit Root Test) uses an Augmented Dickey Fuller (ADF) approach. If the value of the probability value ( $\mathrm{P}$-Value) is less than 0.05 , the data has been stationary at a significant level of five percent (at its level). 
TABLE 1: Results Stationary Test.

\begin{tabular}{|c|c|c|c|}
\hline Variable & Unit Root & P-Value & Conclusion \\
\hline \multirow[t]{3}{*}{ Inflation } & Level & 0.2841 & Not \\
\hline & $1^{s t}$ Difference & 0.0000 & Stationer \\
\hline & $2^{\text {nd }}$ Difference & 0.0000 & Stationer \\
\hline \multirow[t]{3}{*}{ SBI } & Level & 0.4441 & Not \\
\hline & $1^{s t}$ Difference & 0.0000 & Stationer \\
\hline & $2^{\text {nd }}$ Difference & 0.0000 & Stationer \\
\hline \multirow[t]{3}{*}{ Ln_LOAN } & Level & 0.0013 & Stationer \\
\hline & $1^{\text {st }}$ Difference & 0.3471 & Not \\
\hline & $2^{\text {nd }}$ Difference & 0.0000 & Stationer \\
\hline \multirow[t]{3}{*}{ SUN } & Level & 0.1366 & Not \\
\hline & $1^{\text {st }}$ Difference & 0.0000 & Stationer \\
\hline & $2^{\text {nd }}$ Difference & 0.0000 & Stationer \\
\hline \multirow[t]{3}{*}{ SBIS } & Level & 0.4441 & Not \\
\hline & $1^{s t}$ Difference & 0.0000 & Stationer \\
\hline & $2^{\text {nd }}$ Difference & 0.0000 & Stationer \\
\hline \multirow[t]{3}{*}{ Ln_FINC } & Level & 0.0204 & Stationer \\
\hline & $1^{\text {st }}$ Difference & 0.0212 & Stationer \\
\hline & $2^{\text {nd }}$ Difference & 0.0000 & Stationer \\
\hline \multirow[t]{3}{*}{ SBSN } & Level & 0.2677 & Not \\
\hline & $1^{\text {st }}$ Difference & 0.0000 & Stationer \\
\hline & $2^{\text {nd }}$ Difference & 0.0000 & Stationer \\
\hline
\end{tabular}

Based on the results above it can be concluded that model I (conventional monetary policy) is stationary in the 2nd Difference and model II (islamic monetary policy) is stationary in the 1st Difference.

\subsection{Determine lag optimum}

Determination of the optimum lag length is determined by looking at the results of Likehood Ratio (LR), Final Prediction Error (FPE), Akaike Information Criterion (AIC), Schwarz Information Criterion (SC), and Hannan-Quin Criterion (HQ) which are marked with a star symbol (*) Lag with the most asterisks will be the lag chosen for the estimation at the next stage. 
TABLE 2: Lag Optimum Model I.

\begin{tabular}{|c|c|c|c|c|c|}
\hline Lag & LR & FPE & AIC & SC & HQ \\
\hline 0 & NA & $5.5 e-06$ & -0.76 & -0.63 & -0.71 \\
\hline 1 & 58.26 & $3.4 \mathrm{e}-06$ & -1.26 & -0.58 & -0.99 \\
\hline 2 & $67.30^{*}$ & $1.6 \mathrm{e}-06^{*}$ & $-1.20^{*}$ & $-0.78^{*}$ & $-1.51^{*}$ \\
\hline
\end{tabular}

Based on the results, it can be concluded that Model I uses lag 2 as the optimum lag. As for differentiated data, the optimum lag entered is lag 1.

TABLE 3: Lag Optimum Model II.

\begin{tabular}{l|c|c|c|c|c|}
\hline Lag & LR & FPE & AIC & SC & HQ \\
\hline 0 & NA & $9.7 \mathrm{e}-07$ & -2.49 & $-2.35^{*}$ & $-2.43^{*}$ \\
\hline 1 & 32.98 & $9.2 \mathrm{e}-07$ & -2.55 & -1.87 & -2.28 \\
\hline 2 & 21.65 & $1.0 \mathrm{e}-06$ & -2.44 & -1.22 & -1.96 \\
\hline 3 & $35.20^{*}$ & $8.6 \mathrm{e}-07^{*}$ & $-2.63^{*}$ & -0.87 & -1.93 \\
\hline
\end{tabular}

Based on the results, it can be concluded that Model II uses lag 3 as the optimum lag. As for differentiated data, the optimum lag entered is lag 2.

\subsection{Stability test}

The stability test aims to ensure the maximum hose length has been stable. If the modulus value is below one, then the model is stable and produces a valid prediction (Firdaus, 2011).

TABLE 4: Stability Test Model I.

\begin{tabular}{l|l} 
Root & Modulus \\
\hline-0.596061 & 0.596061 \\
-0.455901 & 0.455901 \\
-0.425334 & 0.425334 \\
-0.243791 & 0.243791 \\
\hline Source: Research Result Data 2018) & \\
\hline
\end{tabular}

Based on the results above, it can be concluded that Model I is stable at the length of the shell. 
TABLE 5: Stability Test Model I.

Root
-0.630144
0.602153
$0.141988-0.501532 i$
$0.141988+0.501532 i$
$-0.293473-0.384246 i$
$-0.293473+0.384246 i$
0.396523
-0.298057

\begin{tabular}{|c|}
\hline Modulus \\
\hline 0.630144 \\
\hline 0.602153 \\
\hline 0.521244 \\
\hline 0.521244 \\
\hline 0.483499 \\
\hline 0.483499 \\
\hline 0.396523 \\
\hline 0.298057
\end{tabular}

Source: Research Result Data (2018)

Based on the results in Table 5, it can be concluded that Model II is stable at the length of the shell.

\subsection{Cointegration test}

Cointegration test is important to see the long-term balance between observed variables (Sembiring, 2014). An equation is said to have a cointegration relationship if the trace statistical value or max eigen value is greater than the critical values.

TABLE 6: Cointegration Test Model I.

\begin{tabular}{l|c|c|}
$\begin{array}{l}\text { Hypothesized No. } \\
\text { Of CE (s) }\end{array}$ & Trace Statistic & $\begin{array}{c}\mathbf{0 , 0 5} \text { Critical } \\
\text { Value }\end{array}$ \\
\hline None $^{*}$ & 63.52974 & 47.85613 \\
\hline At most 1 & 24.95101 & 29.79707 \\
\hline At most 2 & 10.87623 & 15.49471 \\
\hline At most 3 & 0.454059 & 3.841466 \\
\hline Source: Research Result Data (2018)
\end{tabular}

Based on the results above, it can be concluded that Model I contained cointegration so that the model used by VECM.

Based on the results above, it can be concluded that Model II contained cointegration so that the model used by VECM. 
TABLE 7: Cointegration Test Model II.

\begin{tabular}{l|c|c|}
$\begin{array}{l}\text { Hypothesized No. } \\
\text { Of CE (s) }\end{array}$ & Trace Statistic & $\begin{array}{c}\mathbf{0 , 0 5} \text { Critical } \\
\text { Value }\end{array}$ \\
\hline None $^{*}$ & 80.62990 & 47.85613 \\
\hline At most $1^{*}$ & 39.60990 & 29.79707 \\
\hline At most 2 & 8.336045 & 15.49471 \\
\hline At most 3 & 0.379048 & 3.841466 \\
\hline Source: Research Result Data (2018)
\end{tabular}

\subsection{Engle-granger causality test}

Engle-Granger Causality test does not actually show causal relationship. Studenmund (2011) said that Granger Causality, or precendence, is a circumstance in which one timeseries variable consistenly and predictably changes before another variable (Runólfsson, Sigurðardóttir, Mixa, \& Carlson, 2017). Despite the value of Granger Causality, however, we shouldn't let ourselves be lured into thingking that it allows us to prove economic causality in any rigorous way. If one variable precedes (Granger causes) another, we can't be sure that the first variable causes the other to the change.

TABLE 8: Causality Test Model I.

\begin{tabular}{|l|c|c|}
\hline Null Hypotheses & Probability & Conclusion \\
\hline Inflation affected SBI & $2 . E-07$ & Significant \\
\hline Inflation affected LOAN & 0.8576 & Not \\
\hline Inflation affected SUN & 0.0733 & Not \\
\hline LOAN affected SBI & 0.0071 & Significant \\
\hline SUN affected SBI & 0.0013 & Significant \\
\hline SBI affected SUN & 0.0139 & Significant \\
\hline Source: Research Result Data (2018) & & \\
\hline
\end{tabular}

Based on Table 8, the results obtained show that when the probability value is below 0.05 , the conventional monetary policy that significantly influences inflation is only the SBI variable. This is because when inflation rises automatically the amount of money in circulation is high, the interest rate from the SBIS will be raised so that people are diverted to save their money compared to spending, in the end the amount of money will decrease. Whereas LOAN and SUN do not have a significant influence on inflation due to the rise and fall of inflation not directly responded by LOAN and SUN and vice versa, where the effect will pass the interest rate first. In addition, the variables that 
have a significant influence on each other are SBI against LOAN and between SBI and SUN.

TABLE 9: Causality Test Model II.

\begin{tabular}{|l|c|c|}
\hline Null Hypotheses & Probability & Conclusion \\
\hline Inflation affected SBIS & $6 . \mathrm{E}-05$ & Significant \\
\hline Inflation affected FINC & 0.0018 & Significant \\
\hline Inflation affected SBSN & 0.0238 & Significant \\
\hline SBIS affected FINC & 0.0010 & Significant \\
\hline SBSN affected SBIS & 0.0097 & Significant \\
\hline SBIS affected SBSN & 0.0117 & Significant \\
\hline SBSN affected FINC & $6 . E-05$ & Significant \\
\hline Source: Research Result Data (2018) & & \\
\hline
\end{tabular}

Based on Table 9, the results obtained show that at the level of five percent, namely when the probability value is below 0.05 , all sharia monetary policies reflected in model II namely SBIS, FINC and SBSN have a significant effect on inflation. This can happen because it becomes a series where when inflation is rising, yields are raised, then SBSN yields increase and finally FINC also increases, then takes place. In addition, the variables that have a significant influence are FINC on SBIS and SBSN and between SBSN and SBIS.

\subsection{Vector error correction model (VECM) test}

The VECM model has proven very useful for describing dynamic behavior from the form of time-series economic and financial data and also for forecasting. This model can provide an estimate of the short-term and long-term effects. This study uses significance with a critical value of $5 \%$, where the t-statistic value is \pm 1.99656 . Variables are stated to have a significant effect if rejecting $\mathrm{HO}$ or accepting $\mathrm{H} 1$ ie when $>1.99656$ and <-1.99656.

Based on Table 10 it can be seen that in the long term that significantly influences inflation is the SBI and SUN. SBI has a negative effect, because an increase in interest rates can limit spending so as to reduce aggregate demand which in turn reduces inflation (Setiawan, 2009).

Meanwhile, SUN has a positive effect, because yield changes affect price levels. Furthermore, prices will affect aggregate demand which ultimately affects the level of real output and inflation (Fauziyah, 2015). 
TABLE 10: VECM Test Model I.

\begin{tabular}{|l|l|l|c|}
\hline & \multicolumn{2}{c}{ Long Term } & \\
\hline Variable & Coefisien & T-Statistic & Conclusion \\
\hline Inflation (-1) & 1.000000 & - & - \\
\hline SBI (-1) & -5.722574 & -6.68427 & Significant \\
\hline LOAN (-1) & -1.536655 & -0.81308 & Not \\
\hline SUN (-1) & 3.739401 & 5.44012 & Significant \\
\hline C & 27.39476 & - & - \\
\hline Variable & \multicolumn{1}{|c|}{ Short Term } & Conclusion \\
\hline Inflation (-1) & Coefisien & T-Statistic & Significant \\
\hline SBI (-1) & 0.308625 & 2.30651 & Not \\
\hline LOAN (-1) & 0.293109 & 0.57778 & Not \\
\hline SUN (-1) & 2.622027 & 0.32824 & Not \\
\hline C & 0.143530 & 0.74781 & Not \\
\hline R-squared & -0.036128 & -0.31883 & Not \\
\hline Adj. R-squared & 0.095245 & - & Not \\
\hline Source: Research Result Data (2018) & & - & \\
\hline
\end{tabular}

In addition, in the short term all of these conventional monetary policy variables have no significant effect on inflation, because in the short term the inflation variable is only influenced by itself in the previous period.

Based on Table 11 it can be seen that in the long term that significantly influences inflation is the variable FINC and SBSN with the direction of positive influence. While the SBIS variable in the long run does not have a significant effect on inflation. This is natural because the Indonesian banking market share is more influenced by conventional banks than Islamic banks (Rusydiana, 2009).

In addition, in the short term that has a significant effect on inflation, is the inflation variable of the previous period and the SBSN with positive influence. Meanwhile, the SBIS and FINC variables in the short term do not have a significant effect on inflation. This is natural because the monetary policy transmission process requires a certain time lag (Noviasari, 2012).

The estimation model in a long term are 
TABLE 11: VECM Test Model II.

\begin{tabular}{|l|l|l|c|}
\hline \multicolumn{1}{c}{ Long Term } & \\
\hline Variable & Coefisien & T-Statistic & Conclusion \\
\hline Inflation (-1) & 1.000000 & - & - \\
\hline SBI (-1) & -5.722574 & -6.68427 & Significant \\
\hline LOAN (-1) & -1.536655 & -0.81308 & Not \\
\hline SUN (-1) & 3.739401 & 5.44012 & Significant \\
\hline C & 27.39476 & - & - \\
\hline & \multicolumn{1}{|c|}{ Short Term } & \\
\hline Variable & Coefisien & T-Statistic & Conclusion \\
\hline Inflation (-1) & 0.308625 & 2.30651 & Significant \\
\hline SBI (-1) & 0.293109 & 0.57778 & Not \\
\hline LOAN (-1) & 2.622027 & 0.32824 & Not \\
\hline SUN (-1) & 0.143530 & 0.74781 & Not \\
\hline C & -0.036128 & -0.31883 & Not \\
\hline R-squared & 0.095245 & - & Not \\
\hline Adj. R-squared & 0.021084 & - & Not \\
\hline Source: Research Results Data (2018) & & \\
\hline
\end{tabular}

Model I

Inflation $=-5.722574 \mathrm{SBI}+2.622027 \mathrm{LOAN}+3.739401 \mathrm{SUN}+27.39476$

Model II

Inflation $=-1.010878$ SBIS +15.72900 FINC +3.876237 SBSN -219.5376

The estimation model in a short term are

Model I

$$
\begin{aligned}
\text { Inflation }= & -0.066171+0.308625 \mathrm{INF}_{(-1)}+0.293109 \mathrm{SBI}_{(-1)} \\
& +2.622027 \operatorname{LOAN}_{(-1)}+0.143530 \mathrm{SUN}_{(-1)}-0.036128
\end{aligned}
$$




\section{Model II}

$$
\begin{aligned}
\text { Inflation }= & -0.073060+0.336496 \mathrm{INF}_{(-1)}-0.224324 \mathrm{INF}_{(-2)} \\
& +0.266667 \mathrm{SBIS}_{(-1)}-0.137542 \mathrm{SBIS}_{(-2)}-6.694776 \mathrm{FINC}_{(-1)} \\
& -5.996001 \mathrm{FINC}_{(-2)}+0.427240 \mathrm{SBSN}_{(-1)}+0.150300 \mathrm{SBSN}_{(-2)} \\
& +0.131521
\end{aligned}
$$

There were separated estimation model, that assumed conventional variable is error term in Islamic model and vice versa.

\subsection{Impulse response function (IRF) test}

\begin{tabular}{|c|c|c|c|c|}
\hline \multicolumn{5}{|c|}{ Response of IHK: } \\
\hline Period & IHK & SBI & LN_LOAN & SUN \\
\hline 1 & 0.70 & 0.00 & 0.00 & 0.00 \\
\hline 2 & 0.87 & 0.09 & 0.03 & -0.06 \\
\hline 3 & 0.87 & 0.11 & 0.02 & -0.14 \\
\hline 4 & 0.85 & 0.17 & 0.01 & -0.17 \\
\hline 5 & 0.83 & 0.10 & 0.01 & -0.19 \\
\hline 6 & 0.81 & 0.10 & 0.01 & -0.20 \\
\hline 7 & 0.81 & 0.10 & 0.01 & -0.20 \\
\hline 8 & 0.80 & 0.10 & 0.01 & -0.20 \\
\hline 9 & 0.80 & 0.10 & 0.01 & -0.20 \\
\hline 10 & 0.80 & 0.10 & 0.01 & -0.20 \\
\hline
\end{tabular}

Impulse-Response Function (IRF) is used to identify a shock on a variable so that it can be seen how an unexpected change in a variable affects other variables.

TABLE 12: IRF Test Model I.

Based on Table 12, the results of the IRF show that the SBI variable can control inflation to be stable in the 5 th month with the influence in the range of $0 \%$ to $0.10 \%$. Then the LOAN variable can control inflation to be stable in the 4th month with the influence in the range of $0 \%$ to $0.03 \%$. And variable SUN can control inflation to stabilize in the 6 th month with the influence in the range of $0 \%$ to $-0.20 \%$. 
TABLE 13: IRF Test Model I.

\begin{tabular}{|c|c|c|c|c|}
\hline \multicolumn{5}{|c|}{ Response of IHK: } \\
\hline Periode & IHK & SBIS & LN_FINC & SBSN \\
\hline 1 & 0.67 & 0.00 & 0.00 & 0.00 \\
\hline 2 & 0.85 & 0.07 & -0.10 & 0.01 \\
\hline 3 & 0.70 & 0.05 & -0.16 & -0.004 \\
\hline 4 & 0.62 & 0.04 & -0.14 & -0.01 \\
\hline 5 & 0.62 & 0.01 & -0.09 & -0.13 \\
\hline 6 & 0.62 & -0.01 & -0.10 & -0.16 \\
\hline 7 & 0.60 & -0.04 & -0.10 & -0.20 \\
\hline 8 & 0.56 & -0.06 & -0.09 & -0.24 \\
\hline 9 & 0.54 & -0.08 & -0.08 & -0.26 \\
\hline 10 & 0.53 & -0.10 & -0.07 & -0.28 \\
\hline
\end{tabular}

Based on Table 13, the results of the IRF show that the SBIS variable can control inflation to stabilize in the 5th month but is only stable within 2 months where the effect is in the range of $-0.08 \%$ to $0.08 \%$. Then the FINC variable can control inflation to stabilize in the 5th to 7th month and the 9th to 10th months with influence in the range of $0 \%$ to $-0.16 \%$. And the last is the SBSN variable cannot control inflation within 10 months, as for its influence in the range of $0.09 \%$ to $0.28 \%$.

\subsection{Forecast error variance decomposition (FEVD) test}

The FEVD results for conventional monetary policy variables show that the influence of SBI, LOAN and SUN is still relatively small. Where it is estimated that up to the 50th month SBI can only explain the inflation rate of $1.33 \%$. Then until the 50th month LOAN can only explain the inflation rate of $0.008 \%$. And the last until the 50th month of SUN can only explain the inflation rate of $5.72 \%$. So that it is estimated that the influence of conventional monetary policy reflected by SBI, LOAN and SUN until the 50th period only describes the inflation variable of $7.06 \%$.

The FEVD results for Islamic monetary policy variables indicate that the effect of SBIS, FINC and SBSN is sufficient. Where it is estimated that up to the 50th month SBIS can explain the inflation rate of $4.77 \%$. Then until the 50th month FINC can explain the inflation rate of $1.28 \%$. And the last until the 50th month of the SBSN can explain the inflation rate of $24.5 \%$. So that it is estimated that the influence of islamic monetary 
policy reflected by SBIS, FINC and SBSN until the 50th period illustrates the inflation variable of $30.55 \%$.

\section{Conclusion}

The results of VECM show that in the short term only SBSN has a significant effect on inflation, but its influence is positive (increasing inflation). In addition in the long term, SBI has a significant negative effect while FINC, SUN and SBSN have a significant positive effect. The effectiveness which is measured by the Impulse Response Function (IRF) and Forecast Error Variance Decomposition (FEVD) shows that conventional monetary policy is faster in stabilizing inflation but the scope is small, while the islamic monetary policy is slower in stabilizing inflation but the scope is bigger.

Therefore, it is expected that the government will continue to improve on conventional and sharia monetary policies that have been implemented. The improvements were made in each of the weaknesses of its monetary policy, conventional monetary policy which only explained a small part of the inflation rate and islamic monetary policy which was slow in controlling inflation. In addition, it should also be noted that other things that are thought to control inflation are stronger, such as the fiat money system.

[1] Ascarya. (2010). Peran Perbankan Syariah dalam Transmisi Kebijakan Moneter Ganda. Iqtishodia: Jurnal Ekonomi Islam Republika, 5.

[2] Ascarya. (2012). Transmission Channel and Effectiveness of Dual Monetary Policy in Indonesia. Bulletin of Monetary Economics and Banking, 269-298.

[3] Ascarya. (2013). Akar Penyebab Krisis Jeuangan Global. Iqtishodia: Jurnal ekonomi Islam Republika, 23.

[4] Ascarya. (2014). Monetary Policy Transmission Mechanism Under Dual Financial System in Indonesia: Interest-profit Channel. International Journal of Economics, 1-32.

[5] Ascarya, Hasanah, H., \& Achsani, N. A. (2008). Perilaku Permintaan Uang dalam Sistem Moneter Ganda di Indonesia. Buletin Ekonomi Moneter dan Perbankan, 5388.

[6] Asnuri, W. (2013). Pengaruh Instrumen Moneter Syariah dan Ekspor Terhadap Pertumbuhan Ekonomi di Indonesia. Al-lqtishad: Vol.V, No.2, 275-288.

[7] Ayuniyyah, Achsani, Ascarya. (2010). Pengaruh Instrumen Moneter Konvensional dan Syariah. Iqtishodia:Jurnal Ekonomi Islam Republika, 6. 
[8] Basuki, A. T., \& Yusuf, A. I. (2018). Aplikasi Model VECM Dalam Riset Ekonomi. Retrieved from ekonometrikblog.wordpress.com/page/2/

[9] BI. (2017, November 19). Transmisi Kebijakan Moneter. Retrieved from Moneter: http: //www.bi.go.id

[10] Creswell, J. W. (2014). Research Design: Qualitative, Quantitative and Mixed Methods Approaches. Singapore: SAGE.

[11] Daniar. (2016). Transmisi Kebijakan Moneter Syariah: Sebuah Analisa. Falah Jurnal Ekonomi Islam Vol.1, 90-102.

[12] Direktorat Jenderal Pengelolaan Utang. (2018). Mengenal Surat Utang Negara. Retrieved from Ministry of Finance.

[13] Fauziyah, F. (2015). Kebijakan Moneter dalam Mengatasi Inflasi di Indonesia. Signifikan Vol. 4, No.1, 83-94.

[14] Finansial Bisnis. (2012). Obligasi dan Instrumen Pendapatan Tetap Lainnya. Retrieved from http://www.finansialbisnis.com/Data2/Riset/Obligasi_2012.pdf

[15] Firdaus. (2011). Aplikasi Ekonometrika untuk Data Panel dan Time Series. Bogor: IPB Press.

[16] Hasibuan, S. (2015). Mekanisme Transmisi Kebijakan Moneter Melalui Suku Bunga SBI Sebagai Sasaran Operasional Kebijakan Moneter dan Variabel Makroekonomi Indonesia. Jurnal Ekonomi dan Keuangan, Vol.1, No.12, 27-40.

[17] Herianingrum, S., \& Syapriatama, I. (2016). Dual Monetary System and Macroeconomic Performances in Malaysia. Journal of Isamic economics, 65-80.

[18] Herinza, R. (2013). Persepsi Ulama Terhadap Pelaksanaan Perbankan Syariah di Kabupaten Kudus. Universitas Negeri Semarang: Skripsi.

[19] Herlina, D. (2013). Identifikasi Mekanisme Transmisi Kebijakan Moneter di Indonesia Tahun 2000-2011. KINERJA Volume 17, No.2, 158-173.

[20] Hismendi, Hamzah, A., \& Musnadi, S. (2013). Analisis Pengaru Nilai Tukar, SBI, Inflasi dan Pertumbuhan GDP Terhadap Pergerakan Indeks Harga Saham Gabungan di Bursa Efek Indonesia. Jurnal IImu Ekonomi Pascasarjana Universitas Syiah Kuala Vol.1, No.2, ISSN 2302-0172, 16-28.

[21] Huston, S. J. (2010). Measuring financial literacy. Journal of Consumer Affairs, XLIV(2), 296-316.

[22] Ismal, R. (2011). Islamic Banking in Indonesia: Lesson Learned. Kertas Kerja dalam Multiyear Expert Meeting on Services, Development and Trade: The Regulatory and Institutional Dimension. United Nations Conference on Trade and Development (UNCTAD), (pp. 1-14). Geneva. 
[23] Isnurhadi. (2014). Pentingnya Pemahaman Tentang Keuangan dan Perbankan Syariah dalam Rangka Mu’amalah yang Berdasarkan Syariah Islam. Orasi IImiah, $1-25$.

[24] Karim, A. (2015). Ekonomi Makro Islami. Jakarta: PT Raja Grafindo Persada.

[25] Karlina, B. (2017). Pengaruh Tingkat Inflasi, Indeks Harga Konsumen Terhadap PDB di Indonesia Pada Tahun 2011-2015. Jurnal Ekonomika dan Manajemen Vol. 6 No. 1 April 2017, 16-27.

[26] Machmud, A., \& Rukmana. (2010). Bank Syariah. Jakarta: Erlangga.

[27] Natsir, M. (2008). Peranan Jalur Suku Bunga dalam Mekanisme Transmisi Kebijakan Moneter di Indonesia. Pustaka Pascasarjana Unhalu Kendari, 1-12.

[28] Noor, F. (2012). Preferensi Masyarakat Pesantren Terhadap Bank Syariah (Studi Kasus DKI Jakarta). TAZKIA Islamic Business and Finance Review, 65-79.

[29] Noviasari, A. (2012). Efektivitas Mekanisme Transmisi Kebijakan Moneter Ganda di Indonesia. Media Ekonomi Vol.20, No.3, 23-48.

[30] Putriani, D., \& Prastowo. (2014). A Critical Review on Interest Rate as A Tool of Monetary Policy. Tazkia Is/amic Finance and Business Review Volume 9.2, 150-165.

[31] Rahardja, P., \& Manurung, M. (2004). Pengantar Ilmu Ekonomi: Mikroekonomi dan Makroekonomi. Jakarta: Fakultas Ekonomi Universitas Indonesia.

[32] Rusdianto, H., \& Ibrahim, C. (2016). Pengaruh Produk Bank Syariah Terhadap Minat Menabung Dengan Persepsi Masyarakat Sebagai Variabel Moderating Di Pati. Equilibrium, $I V(1)$, 43-61.

[33] Rusydiana, A. (2009). Mekanisme Transmisi Syariah pada Sistem Moneter Ganda di Indonesia. Buletin Ekonomi Moneter dan Perbankan, 345-367.

[34] Salju, B. (2017, April 24). Retrieved from Bola Salju: https://bolasalju.com/artikel/ inflasi-indonesia-10-tahun/

[35] Sari, M. D., Bahari, Z., \& Hamat, Z. (2013). Perkembangan Perbanakn Syariah di Indonesia: Suatu Tinjauan. Jurnal Aplikasi Bisnis, III(2), 120-138.

[36] Sembiring, M. (2014). Analisis Vestor Autoregression (VAR) Terhadap Interrelationship Antara IPM dan Pertumbuhan Ekonomi di Sumatera Utara. 1-10.

[37] Setiawan, I. (2009). Analisis Dampak Kebijakan Moneter terhadap Perkembangan Inflasi dan Pertumbuhan Ekonomi di Indonesia . Jurnal Ekonomi, Keuangan, Perbankan dan Akuntansi Vol. 1, No. 1, Mei 2009, 15 - 31

[38] Setyawan, A. R. (2010). Efektivitas Kebijakan Moneter terhadap Inflasi di Indonesia. Jurnal Ekonomi Pembangunan, Vol 8 No. 1 Juli 2010, 281-292.

[39] Silalahi, U. (2012). Metode Penelitian Sosial. Bandung: Refika Aditama. 
[40] Sugianto, Harmain, H., \& Harahap, N. (2015). Mekanisme Transmisi Kebijakan Moneter di Indonesia Melalui Sistem Moneter Syariah. Human Falah, Vol.2, No.1, 50-74.

[41] Surya, B. A., \& Nasher, T. G. (2011). Analisis Pengaruh Tingkat Suku Bunga SBI, Exchange Rate, Ukuran Perusahaan, Debt To Equity Ratio dan Bonds terhadap Yield Obligasi Korporasi di Indonesia . Jurnal Manajemen Teknologi Volume 10 Nomer 2, 186-195.

[42] Sutawijaya, A. (2012). Pengaruh Faktor-faktor Ekonomi Terhadap Inflasi di Indonesia. Jurnal Organisasi dan Manajemen, Volume 8, Nomor 2, September 2012, 85-101.

[43] Wahyudi, A. (2013). Kebijakan Moneter Berbasis Prinsip-prinsip Islam. Justitia Is/amica, Vol. 10/No. 1/Jan.-Juni 2013, 57-80.

[44] Wartoyo. (2014). Persepsi Dan Respon Pesantren Terhadap Implementasi Ekonomi Islam. Retrieved from Portal Garuda: http://download.portalgaruda. org/article.php?article=447042\&val=9458\&title=PERSEPSI\%20DAN\%20RESPON\% 2OPESANTREN\%20\%20TERHADAP\%2OIMPLEMENTASI\%20EKONOMI\%2OISLAM.

[45] Yuliadi, I., Kusuma, D. B., \& Syahputra, A. S. (2016). Dynamics of Inflation Determinants Under Dual Monetary Systems: Empirical Evidences from Indonesia and Malaysia. Jurnal Ekonomi dan Bisnis Islam, Vol. 2, No. 2, Juli-Desember 2016, 149-166.

[46] Yusuf, M., \& Sari, R. K. (2013). Analisis Faktor-faktor yang Mempengaruhi Tingkat Perolehan Margin dengan Akad Murabahah Pada Bank Syariah X. Binus Business Review, 687-696. 